\title{
Arturo Cronia, slavista európskeho formátu
}

\author{
Paolo Di Vico (Nitra)
}

Arturo Cronia: L'eredità di un maestro a cinquant'anni dalla scomparsa. Atti del Convegno di Studi. Padova 20-21 Novembre 2017, a cura di Rosanna Benacchio e Monica Fin. Padova: Esedra Editrice, 2019. 240 pp. ISBN 88-6058-119-2.

(Arturo Cronia: Dedičstvo velikána pri priležitosti pät'desiateho výročia jeho úmrtia. Padova: Esedra Editrice, 2019. 240 s.)

V novembri 2017 sa v Padove konal kongres na pamiatku osobnosti vedca Artura Croniu (1896-1967) pri príležitosti pätdesiateho výročia jeho úmrtia. Predstavovaný zborník príspevkov, venovaných rôznym aspektom mnohostrannej činnosti váženého slavistu, dlhoročného profesora srbského a chorvátskeho jazyka a literatúry a slovanskej filológie na univerzite v Padove, si kladie za ciel' prispiet' $\mathrm{k}$ tomu, aby sa na jeho vzácnu prácu v odbore talianskej slavistiky nikdy nezabudlo, ked’že je považovaný za jedného z jej zakladatelov.

Všetky publikované state kladú dôraz na zložitú škálu kultúrnych záujmov, ktorá charakterizovala činnost̉ Artura Croniu počas jeho dlhoročnej kariéry, v rámci ktorej pedagogicky pôsobil ako v Taliansku, tak aj v zahraničí. Stredobodom záujmu bola jeho nespochybnitelná vedecká príprava a dôležitost̉ jeho štúdií, najmä v niektorých špecifických odvetviach rozlahlej sféry slavistického výskumu, akými sú napríklad srbské, chorvátske, ale aj bohemistické literárne štúdie a $\mathrm{v}$ neposlednom rade práce venované literárnej komparatistike.

Osobitná pozornost’ sa zameriava aj na d’alšie prejavy jeho nenahraditelnej pedagogickej činnosti smerujúcej predovšetkým $\mathrm{k}$ výchove a vzdelávaniu budúcich generácií slavistov, pričom sa snažil aj rozšírit kultúrne dedičstvo, ktoré predstavovala univerzita a jej knižničné služby, ked’že bol zároveň riaditelom bývalého Inštitútu slovanskej filológie tamojšej univerzity, za ktorý bol zodpovedný od roku 1937, ked' nastúpil, až do roku 1967, ked' nás opustil. Obzvlášt činný vo svojej kariére univerzitného pedagóga bol aj ako školitel' nespočetných diplomových prác, ktoré starostlivo viedol v rôznych oblastiach vedy a výskumu.

V mnohých predstavených štúdiách sa pozornosṫ sústred'uje na poskytnutie vyčerpávajúcej panorámy Croniom uprednostňovaných a preferovaných oblastí, napríklad dejiny recepcie Danteho a Petrarcovho diela v českej a slovenskej kultúre, ako aj na to, ako sa poznanie týchto vrcholných autorov talianskej klasickej literatúry odzrkadlilo v srbskej a chorvátskej literatúre. Vo vedeckej činnosti Croniu vzbudil vel'ký záujem výskum zameraný na štúdium českej literatúry, $\mathrm{k}$ čomu prispel aj jeho pobyt, ako prvého slavistu, v novovzniknutej Československej republike, ktorý mu umožnil dôsledné skúmanie zdrojov nachádzajúcich sa v českých archívoch. Počas tohto pobytu pôsobil aj ako pedagóg najprv v Brne, potom v Bratislave a napokon v Prahe. V týchto rokoch Cronia začal prehlbovat najmä kultúrne vzţahy medzi Talianskom a Československom, pričom poukazoval na značný vplyv a vzájomné výmeny medzi týmito dvoma kultúrami. Významná bola predovšetkým jeho pozornost́ venovaná niektorým autorom a dielam, najpodstatnejším pre definíciu hlbokej podstaty intenzívnych vztahov medzi dvoma krajinami. Netreba zabudnút na slová samotného Croniu, ktorý v príspevku v roku 1923 definoval Československo ako „prirodzený stred Európy“, ako „prostredný región“, v ktorom ako „v intelektu- 
álnom strede sa stretávajú v svojich bohatých a rozmanitých prejavoch latinská, germánska a slovanská kultúra“, čím zdôraznil potrebu pre Taliansko a Talianov mat na vedomí tento neuralgický bod európskeho svetadielu. Samozrejme, najvýraznejším aspektom jeho kultúrneho projektu zostáva pokus priniest’ do pozornosti súdobej vedeckej diskusie tému vplyvu talianskej kultúry na českú a slovenskú a v širšom rozmere na všetky slovanské kultúry vo všeobecnosti. Vychádzal pritom z vel'mi podrobného prebádania archívnych materiálov, medzi ktorými vyhladával rukopisy, preklady a akékolvek iné formy talianskeho vplyvu a prítomnosti a podrobil štúdiu najrôznejšie literárne zdroje. Velmi plodný pre jeho akademickú činnost’ bol výskum zameraný na hodnotenie a kritické posúdenie prítomnosti talianskej kultúry a jej literárneho prejavu v chorvátskom prostredí, a to najmä v dielach spisovatelov pôvodom z Dalmácie a Dubrovníka, vtedajšej Ragusy, ktorý nebol vždy primerane akceptovaný chorvátskou stranou, ale napriek tomu predstavuje dôležitú etapu poznania dávnejšej chorvátskej literatúry a jej rozsiahleho kultúrneho dedičstva, ako svedectva kultúrneho poslania na rozmedzí dvoch dimenzií a dvoch realít. Vel'mi zaujímavá, aj kvôli reakciám vyvolaným v akademickom prostredí, ale nielen v ňom, bola jeho reinterpretácia historických zdrojov týkajúcich sa hlaholskej tradície vo Velkej Morave pochádzajúcej z 9. storočia s jej spätným umiestnením v Dalmácii v nasledujúcich storočiach. Zdôraznil tým celú sériu nedorozumení ohladom kanonického stavu hlaholskej liturgie a poskytol novú možnost' overenia poznatkov týkajúcich sa enigmy hlaholizmu. Cronia prostredníctvom svojej výskumnej činnosti bezpochyby dokázal rozvíjat svoj charakteristický a úplne osobný pohlad na srbskú a chorvátsku literatúru, jasne načrtol tie vlastnosti, ktoré považoval za podstatné, aby tento odbor predstavil talianskej verejnosti. Sústredil pritom svoje bádanie na získanie významných stôp talianskeho vplyvu na kontext južných Slovanov, avšak bez opomenutia autochtónneho materiálu, hlavne ludového pôvodu, ktorému vyjadril svoj obdiv a dokázal si zároveň všimnút jeho výraznú umeleckú originalitu v porovnaní s vyššie postavenou dalmátskou literárnou tvorbou. V Croniovom prístupe k chorvátskym literárnym štúdiám je potrebné poukázat na jeho úplne originálne a výrazne osobné postoje a interpretácie, ako sme už naznačili, nezriedka tvoriace zdroj polemík s chorvátskymi vedcami, ktorí Croniu obviňovali z nepriatel'stva, nevraživosti a zaujatosti voči Chorvátom a ich kultúre. Je možné, že tieto polemiky vznikli aj kvôli Croniovemu osobitému presvedčeniu, že talianska kultúra svojím vyžarovaním do slovanského sveta už v renesančnej dobe, ale aj počas nasledujúcich epoch až do súčasnosti, prispela v ňom, len vd’aka sebe samej, k rozkvetu umeleckého vyjadrenia.

Napokon nesmieme zabudnút na všetky jeho práce zamerané na dôkladné pochopenie slovanského sveta a jeho rozmanitých prejavov, adresované talianskemu čitatel'ovi, ktoré predstavujú takmer historickú a bibliografickú bilanciu dlhoročných výskumov a našli svoje uplatnenie v presne definovaných vedeckých a záujmových oblastiach. Jeho najznámejšie dielo v tomto smere Poznanie slovanského sveta v Taliansku predstavuje a ponúka obrovské množstvo materiálu o tisícročných vztahoch medzi Talianskom a slovanským svetom, pričom dokáže určit ich dôvody a vývoj a zároveň poskytuje pevné teoretické základy pre akýkolvek možný budúci rozvoj slavistického výskumu. Cronia sa trvalo snažil dokázat' každým možným spôsobom, že Taliansko nikdy nezaujalo voči slovanskému svetu lahostajný postoj a ani úplne neodignorovalo jeho kultúrne a lingvistické prejavy, že jeho znalosti neboli obmedzené len na obdobie po prvej svetovej vojne a na starostlivo vybrané krajiny, akými boli Pol'sko a Rusko. Záujem Talianska o slovanskú realitu s jej polyedrickými aspektmi je v skutočnosti, ako potvrdzuje Cronia, ovela skorší a dal by sa považovat za jeden z najskorších v európskom prostredí. Z tohto predpokladu sa vyvíja jeho analýza podporená bohatou a nekonečnou bibliografiou, ktorá potvrdzuje dielo Croniu ako mílnika talianskej slavistiky, a to nielen ako nevyčerpatelného zdroja informácií a podnetov pre výskum, ale aj ako študijný nástroj, ktorý tým, že 
poznačil dobu, sa postupne sám mení na pred- k úplnému pochopeniu ideologického obsahu, met výskumu, na takmer povinnú oblast', a to vd’a- estetických a literárnokritických presvedčení, ako ka svojmu nastaveniu, ktoré nám umožní dospię aj osobnosti jeho autora.

\section{Mgr. Paolo Di Vico}

\section{Katedra romanistiky}

Filozofická fakulta, Univerzita Konštantína Filozofa v Nitre

Hodžova 1, 94974 Nitra, SK

pdvico@ukf.sk 